\title{
Pesticide Usage Pattern and Farmers Perception in Curry Leaf [Murraya Koeinigii (L.) Sprengel]
}

\author{
Swarupa, S, Shashi Vemuri and V.Venkateswar Reddy ${ }^{1}$ \\ AINP on Pesticide Residues, PJTSAU, Rajendranagar, Hyderabad
}

\begin{abstract}
Curryleaf [Murraya koeinigii (L.) Sprengel] exported from India had insecticide residues above maximum residue limits, which are hazardous to consumer health and caused rejection of the commodity at point of entry in Europe and middle east resulting in a check on export of curry leaf. Hence to study current pesticide usage patterns in major curry leaf growing areas, a survey on pesticide use pattern was carried out in curry leaf growing areas in Guntur districts of Andhra Pradesh during 2013-14, by interviewing farmers growing curry leaf utilizing a questionnaire to assess their knowledge and practices on crop cultivation, general awareness on pesticide recommendations and use. Education levels of farmers were low, wherein 13.96 per cent were only high school educated and $13.96 \%$ were illiterates. $18.60 \%$ farmers were found cultivating curry leaf in less than 1 acre of land, $32.56 \%$ in 2-5 acres, $20.93 \%$ in 5-10 acres and $27.91 \%$ of the farmers in more than 10 acres of land.. Majority of the curry leaf farmers (93.03\%) used pesticide mixtures rather than applying single pesticide at a time, basically to save time, labour, money and to combat two or more pests with single spray. About 53.48\% of farmers applied pesticides at 2 days interval followed by 34.89\% of the farmers at 4 days interval and about $11.63 \%$ of the farmers sprayed at weekly intervals. Only $27.91 \%$ of farmers thought that the quantity of pesticides used at their farm is adequate, $90.69 \%$ of farmers had perception that pesticides are helpful in getting good returns. $83.72 \%$ offarmers felt that crop change is the only way to control sucking pests which damages whole crop. About $4.65 \%$ of the curry leaf farmers opined that integrated pest management practices are alternative to pesticides and only $11.63 \%$ of farmers felt natural control as an alternative to pesticides. About $65.12 \%$ of farmers had perception that high pesticide dose will give higher yields. However, in general, Curry leaffarmers preferred to contact pesticide dealers (100\%) and were not interested to contact either agricultural officer or a scientist. Farmers were aware of endosulfan ban 93.04\%), in contrast only 65.12 per cent of farmers knew about the ban of monocrotophos on vegetables. Very few farmers knew about pesticide residues and decontamination by washing. Extension educational interventions are necessary to produce fresh curry leaf free from pesticide residues.

Keywords: Murraya koeinigii, leaf roller, Curry leaf, Psyllids, endosulfan, decontamination Tetranychid mite
\end{abstract}

\section{Introduction}

Curry leaf [Murraya koeinigii (L.) Sprengel] belonging to family Rutaceae, is a native of Sri lanka. It is also seen in Burma, Huawei, South china and Indo-China and widely distributed in dry regions. In India, it is widely used in Kerala and Andhrapradesh and cultivated in south Indian states viz. Tamil Nadu, Kerala and Andhra Pradesh. It is a major ingredient in Indian cuisine, due to its aroma which is due to the presence of volatile oils. Due to high demand in Ayurveda medicinal use and culinary purpose, the commercial cultivation of curry leaf was started in some parts of southern states in India. Exports of curry leaf from India contained insecticide residues above maximum residue limits, which can be hazardous to consumer health and caused rejection of the commodity at point of entry. It is important to study current insecticide usage patterns in major curry leaf growing areas. Farmers feel it necessary to use larger quantities of insecticides causing greater than accepted levels of residues on the products. In Andhra Pradesh and Telangana curry leaf cultivation as a commercial crop is mostly confined to areas in Guntur, Krishna, Nellore, Medak and Nizamabad districts. Since it was hitherto grown in back yards, near the farm houses and cattle sheds and also due to the fact that not much damage is caused by pests and diseases the usage of pesticides was almost negligible. However, due to the increased crop area and changing scenario of weather, many pests and diseases are noticed, infesting the crop significantly both in quality \& quantity. There is little known information on pesticide use in curry leaf, but it was determined that the chemicals used were potent and potentially dangerous if used incorrectly. Tara and Monika (2010) recorded 12 insect pests in 10 families of five insect orders infesting curry leaf plants in districts Jammu, Kathua, Udhampur, and Samba of Jammu region. Psorosticha zizyphi Stainton and Diaphorina communi Kuwayama (Homoptera) are major pests causing extensive damage.( Devaki et al, 2012) The major insect pests noticed in this crop are citrus butterfly, psyllids, scales, mealy 
bugs and the fungal pathogen causing leaf spots causing crop losses both in terms of quality and quantity in curry leaf. This has resulted in farmers taking up pesticide sprays with an intention to obtain remunerative price and increased yield thus spoiling the quality of the leaves (Ramakrishnan et al 2015). Thus lead to the Pesticide residue on foliage, an important export commodity from India, rich in vitamin A and calcium (Khan et al., 1997). The plant has been identified as one of five vegetables with export potential. Fresh leaves are mainly exported to Persian Gulf and European nations. However, exported products can be contaminated with high residual concentrations of the insecticides resulting in rejection of the commodity (Mutwakil et al.,2009; Pinyupa et al.,2009). There are currently no insecticide recommendations for curry leaf and hence no threshold levels. Producers use pesticides that are designed to control the insect even if there are no recommendations for the crop. Pesticides are applied irrespective of whether the pest is present or not. To promote appropriate use of insecticides, it is critical to understand their current use in major curry leaf growing areas. There have been no published reports regarding insecticide use patterns in curry leaf. Hence, a survey was taken up to explore insecticide use patterns among curry leaf farmers.

\section{Materials and methods}

Survey on pesticide usage on Curry leaf was carried out at farmer fields of 6 villages of Mangalagiri mandal, Guntur district of Andhra Pradesh based on the considerable area under Curry Leaf cultivation. A questionnaire was prepared to collect the data scientifically for statistical analysis on various parameters such as type of pesticides used at different crop growth stages, target pests and commonly occurring pests, waiting period followed for harvesting after application of pesticides and other socio economic aspects. Details of locations for field study is presented in Table -1.

Table 1. Details of locations of survey conducted in curry leaf growing areas of Guntur district

\begin{tabular}{|l|l|l|c|}
\hline SI.No & Mandal & Village & Sample farmers \\
\hline \multirow{4}{*}{1} & Mangalagiri & Gudimeda & 3 \\
\cline { 3 - 4 } & Ippatam & 8 \\
\cline { 3 - 4 } & Pedavadlapudi & 11 \\
\cline { 3 - 4 } & Revendrapadu & 5 \\
\cline { 3 - 4 } & Nutakki & 9 \\
\cline { 3 - 4 } & Tummapudi Total & 7 \\
\hline
\end{tabular}

These investigations were undertaken to study Curry leaf farmers perception and demand for pesticide usage, management and their health effects on farmers. Formal and informal interviews were used to establish the relation between education level of farmers and safety measures adopted by them for pesticide usage at different crop growth stages, dose of pesticides, target pests and commonly occurring pests, waiting period followed for harvesting after application of pesticides and other socio economic aspects etc.

\section{General characteristics of farmers:}

\section{Results and discussion}

\section{Age of the farmers}

Around $16.28 \%$ of the farmers were in the age group of $>50$ years followed by $40-50$ years $(55.81 \%), 30-40$ years (16.28\%) and 20-30 years (11.63\%). The analysis of education level of respondents showed that $2.32 \%$ of respondents had college education; $13.96 \%$ farmers studied upto high school; $2.32 \%$ farmers had secondary education; $67.44 \%$ farmers with primary school education and $13.96 \%$ farmers were illiterates. About $88.37 \%$ of the farmers belonged to nuclear family and $11.62 \%$ of farmers belonged to joint family.(Table-2)

\section{General information on curry leaf cultivation}

Age of the crop: More than $11.63 \%$ of crops were 1 year old, $39.53 \%$ of the crops were 2 to 5 years old, $16.28 \%$ of the crops were of 5-10 years and $32.56 \%$ were above 10 years old. Farmers usually had good awareness regarding selection of the seed and all the cultivation practices etc. $18.60 \%$ farmers were found cultivating curry leaf crop in less than 1 acre of land, $32.56 \%$ in 2-5 acres, $20.93 \%$ in 5-10 acres and $27.91 \%$ of the farmers in more than 10 acres of land. Some farmers were cultivating curry leaf in 30 to 40 acres of land since last 30 years. About $11.63 \%$ of the curry leaf farmers were aware of recommended pesticides against different pests and about $9.30 \%$ of respondents were aware of pesticide classification based on toxicity. It is observed that due to less literacy level of curry leaf farmers, only few were keen in knowing pesticide recommendations and large number of farmers were using pesticides without knowing recommendations. Majority of farmers are illiterates and literate's negligence led to application of pesticide without proper recommendation. Most of the farmers were unaware of pesticide 
Pesticide Usage Pattern and Farmers Perception in Curry Leaf [Murraya KOEINIGII (L.) Sprengel]

classification based on toxicity. Both these issues might be attributed to literacy level, insufficient extension activities and also negligence of farmers.(Table-3)

Following safe methods while storing / mixing / spraying pesticides

About $18.6 \%$ of farmers followed safe methods while storing or mixing or spraying pesticides. About $25.58 \%$ of farmers measured chemical by bottle cap and $74.42 \%$ farmers measured approximately. About $11.63 \%$ of farmers mixed chemical with bare hands and $88.37 \%$ mixed with stick. Majority of the farmers did not follow safe methods while storing or mixing or spraying pesticides, and it might be attributed to non availability of protective coverings and lack of awareness of pesticide effect on health. More than half of the respondents measured chemicals approximately as most of them were unaware of recommendations. The farmers, who were concerned about pesticide ingestion along with the food, mixed chemical with stick and not with hands, but few farmers who were careless about ill effects of pesticides, mixed pesticides with bare hands(Table-4)

Pesticide effect on health of spray men and first aid followed

Most of the respondents observed pesticide effect on health of spray men during spray. Most common health problems observed during spray in curry leaf fields include skin irritation $(20.93 \%)$, cough (11.63\%), eye irritation (20.93\%), bad odour (37.21\%) and head ache (9.30\%).To combat these effects, majority of farmers used first aid methods like induced vomiting if pesticide is swallowed (9.30\%), washing the affected area with water (20.93\%) and washing the affected area with soap water $(69.77 \%)$. All the farmers experienced some or the other problems, due to improper protective coverings, eating or smoking during pesticide application and not having proper bath after pesticide application. Farmers usually followed simple first aid practices which were helpful to victim until he was taken to hospital.

Awareness on banned insecticides Majority of the famers had good awareness of ban of endosulfan in agriculture (93.04\%), in contrast only $65.12 \%$ of famers were aware that monocrotophos is banned for use on vegetables. The fact set of the farmers were aware about endosulfan ban in agriculture, might be due to kasargod incident which became global. $34.88 \%$ of the farmers were unaware of ban of monocrotophos in vegetables and this might be due to insufficient extension activities. (Table-4)

Contact person for pesticide recommendations: Curry leaf farmers preferred to contact pesticide dealers (100\%) and were not interested to contact either agricultural officer or a scientist .All the farmers contacted pesticide dealers because farmers feel that dealers are having more experience in recommending pesticides and most often they neglect to contact agricultural officers and scientists as they have to travel some distance to contact them and have less rapport with these officials when compared to pesticide dealers.

Pesticide mixtures and frequency of pesticide application: Majority of the curry leaf farmers $(93.03 \%)$ used pesticide mixtures rather than applying single pesticide at a time, basically to save time, labour, money and to combat two or more pests with single spray. About 53.48\% of farmers applied pesticides at 2 days interval followed by $34.89 \%$ of the farmers at 4 days interval and about $11.63 \%$ of the farmers sprayed at weekly intervals. The fact that the curry leaf farmers applied pesticides at 2-4 days interval shows that farmers are more keen about the crop health.

Awareness on pesticide residues: Only $65.12 \%$ of curry leaf famers were aware that pesticide residues are found in vegetables and only $23.25 \%$ of curry leaf farmers knew that pesticide residues in food enter into body and accumulate. Not even a single farmer was aware that for each pesticide, pre-harvest interval is recommended. Common waiting period of one day (79.07\%) was followed by most of the curry leaf farmers and $20.93 \%$ followed 2 days PHI (Post Harvest Interval). About $46.51 \%$ of the curry leaf farmers knew that pesticide residues in the food cause cancer, $30.24 \%$ of the farmers know that residues in the food causes other health effects and about $23.25 \%$ of farmers responded that they did not hear any kind of bad effects due to pesticide residues. Majority of curry leaf farmers were unaware of pesticides residues, their bad effects, pre harvest intervals and this might be attributed to literacy level of the farmers and insufficient extension activities.( Table-4A)

Awareness of decontamination methods: Majority (76.75\%) of curry leaf farmers were aware of decontamination with normal water. Washing curry leaf before sending to the market was done by all the farmers for the removal of pesticides and to keep the leaves fresh during transportation. About $23.25 \%$ of the farmers also knew that salt water washing helps to remove pesticide residues. Majority of the farmers were unaware of various decontamination methods, but as a regular kitchen practice they wash curry leaf with tap water along with the other vegetables.

Perception of farmers about pesticides and alternative methods of pest control:

Among the curry leaf farmers only $27.91 \%$ of farmers thought that the quantity of pesticides used at their farm is adequate, and about $90.69 \%$ of farmers had perception that pesticides are helpful in getting good returns. About $83.72 \%$ of farmers felt that crop change is the only way to control sucking pests which damages whole crop. About $4.65 \%$ of the curry leaf farmers opined that integrated pest management practices are alternative to pesticides and 
Pesticide Usage Pattern and Farmers Perception in Curry Leaf [Murraya KOEINIGII (L.) Sprengel]

only $11.63 \%$ of farmers felt natural control as an alternative to pesticides. About $65.12 \%$ of farmers had perception that high pesticide dose will give higher yields. Majority of the farmers thought that pesticides are helpful in getting good returns and very few states that integrated pest management practices and natural control measures are alternative to pesticides. This might be due to non-availability of natural pest control /management components, slow knock down of pests when compared to chemical pesticides and lower yields in initial years in case of natural control.

\section{Use of empty pesticide bottles and their disposal}

It was observed that majority of the farmers (30.24\%) simply throw empty bottles in trash and few farmers (69.76\%) also opined that they sell empty bottles. Proper disposal of empty pesticide bottles without using them for house or farm purpose is essential in order to avoid health hazards due to pesticides. Curry leaf farmers were not using pesticide bottles for house or farm purposes as they were aware of bad effects of pesticides. Disposal of theses empty pesticides bottles was not carried out in a satisfactory way, as majority of the farmers were simply selling the bottles.

Information on occurrence of insect pests Curry leaf farmers feel that the major destruction of the crop is due to the Two spotted mites (Tetranychus spp.) followed by Scales (Coccoidea spp.), Aphids(Toxoptera aurantii),Citrus leaf miner (Phyllocnistis citrella) leaf roller, Citrus mealy bugs(Planococcus citri), Asian Citrus Psyllids (Diaphorina citri), Leaf eating caterpillar (Spodoptera litura), White fly (Aleurodicus disperses) and Citrus butterfly (Papilio polytes) in the range of 100, 97.66, 97.66, 93.02, 86.04, 81.39, 55.81, 46.51, and 23.25\%, respectively. The farmers are slowly shifting to other crops due to more pest infestation and due to increase in resistance of pests to different pesticides.(Table-5)

\section{Types of pesticides used by curry leaf growers}

Major pesticides used by the curry leaf farmers are Imidacloprid 17.8\% SL, Bifenthrin 10\% EC, Profenophos $72 \%$ EC, Acephate 75\% WP, Imidacloprid 70\%WG, Profenophos 40\%EC, Chlorpyrifos 20\%, Triazophos 40\%, Chlorantraniliprole, Acetamiprid 20\%SP, Thiomethaxim 25\% WG, Diafenthiuron 50\% SC, Carbendazim 50\% WP, Monocrotophos 36\% SL, Bifenthrin 250\% EC, Carbosulfan 25\% SD and Spiromesifen 22.9\% SC, where 100.00\%, 97.67\%, 97.67\%, 95.34\%, 95.34\%, 93.02\%, 90.69\%, 81.39\%, 81.39\%, 69.76\%, 53.48\%, 51.16\%, 41.18\%, 39.53\%, $30.23 \%, 27.90 \%$ and $13.95 \%$ farmers used above pesticides, respectively.( Table-6) Nagendra (2002) reported that only $5.8 \%$ of respondents contacted agricultural officers for suggestions on pest control, and in present study also only $15 \%$ of respondents contacted agricultural officers for suggestions which is in line with the work done by the Jana et al. (2012). The highly educated and also progressive farmers in their crop management usually contact specialist instead of local Agricultural Officer for suggestions. In present study growers had awareness of pesticide recommendations which are in conformity with the findings of Hosamani (2009), Nagendra (2002) and Jana et al. (2012) who reported $8.33 \%, 11.67 \%$ and $25 \%$ of respondents aware of pesticide recommendations, respectively. Usually, very few farmers will have knowledge on pesticide recommendations as per Act and GAPs of ICAR and SAUs, and are fully depend on neighbour farmer, local dealer or press / media reports, and in most cases pesticide dealer, except in case of progressive farmers and also vegetable growers for export purposes, who follow GAPs to avoid the pesticide residues. Awareness of pesticide classification based on toxicity indicated that very few farmers look at the colour code triangle on the pesticide bottle, as reported by Nagendra (2002) and Raghu (2015) who showed $14.17 \%$ and $27.50 \%$ of respondents had awareness of pesticide classification based on toxicity respectively. These reports depend on place, crop, purpose of product, use of the product, size of the pack etc. and it is necessary to educate the farmers on the toxicity codes of pesticides and care to be taken while handling the same at both farm and home level. In present study growers mixed pesticide with wooden stick and not with bare hands, and the results are in agreement with the findings of Patil et al. (2012) and Raghu( 2015) who observed that $64.17 \%$ and $57 \%$ of respondents mixed pesticide with wooden stick and not with bare hands. Present investigation revealed growers have not used empty pesticide bottles for house/farm purpose, which is in line with the findings of Nagendra (2002) and Jana et al. (2012) who reported 85\% and 53\% of respondents have not used empty pesticide bottles for house/farm purpose, respectively. Further it was noticed that very few farmers try to sell the empty bottles to rag buyers, but no farmer is aware of the scientific disposal procedures for used packs / bottles. In the present study, most farmers felt that bad odour of pesticides is harming people, and noticed common health problems like skin irritation, cough, eye irritation, head ache, breathlessness in the spray men during and after spray operations at farm level. Similar observations were also noticed by farmers growing curry leaf in open fields, and few had head ache. These findings are in agreement with the findings of Nagendra (2002) who reported $97.43 \%$ and 
$51.67 \%$ of skin irritation, respectively. Nagendra (2002) and Jana et al. (2012) recorded eye irritation (44.17\% respondents), 35.83 and $22.00 \%$ had head ache, among the farmers engaged in spraying of pesticides and). Jana $e t$ al. (2012) reported that $70 \%$ of the respondents experienced bad odour which is in line with the findings of present investigation.

Table 2.General characteristics of the farmers growing curry leaf

\begin{tabular}{|c|c|c|c|}
\hline SI.No & Particulars & Frequency & Percentage \\
\hline \multirow[t]{5}{*}{1.} & \multicolumn{3}{|l|}{ Age } \\
\hline & $20-30$ & 05 & 11.63 \\
\hline & $30-40$ & 07 & 16.28 \\
\hline & $40-50$ & 24 & 55.81 \\
\hline & $>50$ & 07 & 16.28 \\
\hline \multirow[t]{6}{*}{2.} & \multicolumn{3}{|l|}{ Educational status } \\
\hline & Illiterate & 06 & 13.95 \\
\hline & Primary school & 29 & 67.44 \\
\hline & Secondary school & 01 & 2.32 \\
\hline & High school & 06 & 13.96 \\
\hline & College & 01 & 2.32 \\
\hline \multirow[t]{3}{*}{3.} & \multicolumn{3}{|l|}{ Type of family } \\
\hline & Nuclear & 38 & 88.37 \\
\hline & Joint & 5 & 11.62 \\
\hline
\end{tabular}

Note: Figures in percentage are with respect to their respective frequency $(n=43)$

Table 3.. General information regarding curry leaf cultivation

\begin{tabular}{|c|c|c|c|}
\hline SI.No & Particulars & Frequency & Percentage \\
\hline \multirow[t]{5}{*}{1} & \multicolumn{3}{|c|}{ Age of the crop } \\
\hline & 1 year & 5 & 11.63 \\
\hline & $2-5$ years & 17 & 39.53 \\
\hline & 5-10years & 7 & 16.28 \\
\hline & $>10$ years & 14 & 32.56 \\
\hline \multirow[t]{5}{*}{2} & \multicolumn{3}{|l|}{ Crop area } \\
\hline & $<$ 1acre & 8 & 18.60 \\
\hline & $2-5$ acres & 14 & 32.56 \\
\hline & 5-10 acres & 9 & 20.93 \\
\hline & $>10$ acres & 12 & 27.91 \\
\hline
\end{tabular}

Table 4.. General awareness of farmers on pesticides and their use

\begin{tabular}{|c|c|c|c|c|c|}
\hline \multirow[t]{2}{*}{ SI.No } & \multirow[t]{2}{*}{ Particulars/comments } & \multicolumn{2}{|c|}{ Frequency } & \multicolumn{2}{|c|}{ Percentage } \\
\hline & & Yes & No & Yes & No \\
\hline 1 & Are you aware about recommended pesticides against different pests & 5 & 38 & 11.63 & 88.37 \\
\hline 2 & Are you aware about the pesticide classification based on toxicity & 4 & 39 & 9.30 & 90.70 \\
\hline 3 & Do you follow safe methods while storing / mixing / spraying pesticides & 8 & 35 & 18.60 & 81.40 \\
\hline 4 & Do you observe pesticide effect on health of spray men during spray & 43 & 0 & 100.00 & 0.00 \\
\hline 5 & Are you aware that endosulfan is banned for use & 40 & 3 & 93.04 & 6.97 \\
\hline 6 & Are you aware that Monocrotophos is banned for use on vegetables & 28 & 15 & 65.11 & 34.88 \\
\hline 7 & Do you use pesticide mixtures & 40 & 3 & 93.03 & 6.97 \\
\hline 8 & Are you aware that for each pesticide, pre-harvest interval is recommended & 0 & 43 & 0.00 & 100.00 \\
\hline 9 & Are you aware that pesticide residues are found in vegetables & 28 & 15 & 65.12 & 34.88 \\
\hline 10 & Do you know that pesticide residues in food enter into body and accumulate & 10 & 13 & 23.25 & 76.75 \\
\hline 11 & Are you aware about pesticide decontamination method & 30 & 13 & 69.77 & 30.23 \\
\hline 12 & Are you aware that food exports are rejected due to pesticide residues & 5 & 38 & 11.63 & 88.37 \\
\hline 13 & Do you think the quantity of pesticides used as adequate & 12 & 31 & 27.91 & 72.09 \\
\hline 14 & Do you think that pesticides are helpful in getting good returns & 39 & 4 & 90.69 & 9.31 \\
\hline 15 & Do you think high pesticide dose gives higher yields & 28 & 15 & 65.12 & 34.88 \\
\hline 16 & Use of empty bottles for house / farm purpose & 0 & 43 & - & 100.0 \\
\hline
\end{tabular}


Table-4 A General awareness of farmers on pesticides and their use

\begin{tabular}{|c|c|c|c|}
\hline SI.No & Particulars/comments & Frequency & Percentage \\
\hline \multirow[t]{3}{*}{17} & \multicolumn{3}{|l|}{ How do you measure the chemical } \\
\hline & Bottle cap & 11 & 25.58 \\
\hline & Approximately & 32 & 74.42 \\
\hline \multirow[t]{3}{*}{18} & \multicolumn{3}{|l|}{ How do you mix the chemical } \\
\hline & Bare hands & 5 & 11.63 \\
\hline & Stick & 38 & 88.37 \\
\hline \multirow[t]{7}{*}{19} & \multicolumn{3}{|c|}{ Most common health problem observed during spray } \\
\hline & Skin irritation & 9 & 20.93 \\
\hline & Cough & 5 & 11.63 \\
\hline & Breathlessness & 0 & 0.00 \\
\hline & Eye irritation & 9 & 20.93 \\
\hline & Bad odour & 16 & 37.21 \\
\hline & Head ache & 4 & 9.30 \\
\hline \multirow[t]{4}{*}{20} & \multicolumn{3}{|l|}{ Best first aid you follow } \\
\hline & Induce vomiting if swallowed & 4 & 9.30 \\
\hline & Washing the affected area with water & 9 & 20.93 \\
\hline & Washing the affected area with soap water & 30 & 69.77 \\
\hline \multirow[t]{4}{*}{21} & \multicolumn{3}{|c|}{ Whom you contact, for pesticide recommendations } \\
\hline & Agricultural officer & 0 & 0.00 \\
\hline & Dealer & 43 & 100.00 \\
\hline & Scientist & 0 & 0.00 \\
\hline \multirow[t]{4}{*}{22} & \multicolumn{3}{|l|}{ How frequently you apply the pesticides } \\
\hline & 2 Days & 23 & 53.48 \\
\hline & 4 days & 15 & 34.89 \\
\hline & Week & 05 & 11.63 \\
\hline \multirow[t]{5}{*}{23} & \multicolumn{3}{|c|}{ Common waiting period you follow after pesticide spray } \\
\hline & 1 Day & 34 & 79.07 \\
\hline & 2 Day & 9 & 20.93 \\
\hline & 4 Day & 0 & 0.00 \\
\hline & Week & 0 & 0.00 \\
\hline \multirow[t]{4}{*}{24} & \multicolumn{3}{|c|}{ What type of bad effects you heard due to pesticide residues in food } \\
\hline & Cancer & 20 & 46.51 \\
\hline & Physical impairments & 13 & 30.24 \\
\hline & Not heard any bad effects & 10 & 23.25 \\
\hline \multirow[t]{3}{*}{25} & \multicolumn{3}{|c|}{ Common method of decontamination followed } \\
\hline & Salt water wash & 10 & 23.25 \\
\hline & Water wash & 33 & 76.75 \\
\hline \multirow[t]{4}{*}{26} & \multicolumn{3}{|l|}{ Best alternative for pesticide use } \\
\hline & Crop change & 43 & 100.00 \\
\hline & Natural control & 0 & 0.00 \\
\hline & Integrated pest management & 0 & 0.00 \\
\hline \multirow[t]{4}{*}{27} & \multicolumn{3}{|c|}{ What is the disposal method you follow for empty pesticide bottles } \\
\hline & Bury in soil & 0 & 0.00 \\
\hline & Sell & 30 & 69.76 \\
\hline & Throw in to trash & 13 & 30.24 \\
\hline
\end{tabular}

Note: Figures in percentage are with respect to their respective frequency $\quad(n=43)$

Table 5. Information on occurrence of insect pests

\begin{tabular}{|l|l|l|l|l|}
\hline SI. No & Insect pest & Scientific name & Frequ-ency & Percentage \\
\hline 1 & Scales & Coccoidea spp. & 42 & 97.67 \\
\hline 2 & Citrus butterfly & Papilio polytes & 10 & 23.25 \\
\hline 3 & Aphids & Toxoptera aurantii & 42 & 97.67 \\
\hline 4 & Citrus mealy bugs & Planococcus citri & 37 & 86.04 \\
\hline 5 & Citrus leaf miner & Phyllocnistis citrella & 40 & 93.02 \\
\hline 6 & Asian Citrus Psyllids & Diaphorina citri & 35 & 81.39 \\
\hline 7 & Two spotted mites & Tetranychus spp. & 43 & 100.00 \\
\hline 8 & White fly & Aleurodius indicus & 20 & 46.51 \\
\hline 9 & Leaf eating caterpillar & (Spodoptera litura) & 24 & 55.81 \\
\hline
\end{tabular}

Note $: n=43$ 
Table 6. Types of pesticides used by curry leaf growers

\begin{tabular}{|l|l|l|l|l|}
\hline SI.NO & Chemical name & Trade name & Frequency & Percentage \\
\hline 1 & Profenophos 40\%EC & Carina & 40 & 93.02 \\
\hline 2 & Triazophos 40\% & Hostothion & 35 & 81.39 \\
\hline 3 & Imidacloprid 70\%WG & Admire & 41 & 95.34 \\
\hline 4 & Acetamiprid 20\% SP & Pride & 30 & 69.76 \\
\hline 5 & Carbosulfan 25\% SD & Marshall & 12 & 27.90 \\
\hline 6 & Bifenthrin 10\% EC & Marker & 42 & 97.67 \\
\hline 8 & Acephate 75\% WP & Orthene & 41 & 95.34 \\
\hline 9 & Imidacloprid 17.8\% SL & Confidor & 43 & 100.00 \\
\hline 10 & Chlorpyrifos 20\% \& 50\% EC & Chlorogaurd & 39 & 90.69 \\
\hline 11 & Thiomethaxim 25\% WG & Actara & 23 & 53.48 \\
\hline 12 & Bifenthrin 250\% EC & Tallstar & 13 & 30.23 \\
\hline 13 & Monocrotophos 36\% SL & Monostar & 17 & 39.53 \\
\hline 14 & Spiromesifen 22.9\% SC & Oberon & 6 & 13.95 \\
\hline 15 & Chlorantraniliprole & Coragen & 35 & 81.39 \\
\hline 16 & Profenophos 72\% EC & Curacron & 42 & 97.67 \\
\hline 17 & Diafenthiuron 50\% SC & Polo & 22 & 51.16 \\
\hline
\end{tabular}

Note: Figures in percentage are with respect to their respective frequency $(\mathbf{n}=\mathbf{4 3})$

\section{References}

[1]. Devaki, K., Muralikrishna, T., Sreedevi, K and Rao, A. R. 2012. Incidence and biology of leaf roller, Psorosticha zizyphi (Stainton) (Lepidoptera:Oecophoridae) on curry leaf, Murraya koenigii (L.) Sprengel. Pest Management in Horticultural Ecosystems. 18 (2): 154-157.

[2]. Jana, H., Kole, R. K., Basu, D and Maity, S. S. 2012a. Vegetable growers "extent of precautions in application of pesticides" in Nadia district of West Bengal. Pestology. 36 (7): 29-33.

[3]. Jana, H., Kole, R. K., Basu, D and Maity, S. S. 2012b. Problems faced by vegetable growers in using pesticides in Hoogly district of West Bengal. Pestology. 36 (11): 38-42.

[4]. Khan, B.A., A. Abraham, and S. Leelamma. 1997.Antioxidant effects of curry leaf, Murraya koenigii and mustard seeds, Brassica juncea in rat fed with high fat diet.Indian J. Exp. Biol. 35(2):148-150.

[5]. Mutwakil, M. A., Malil, E. M and Vijay, P. 2009. Monitoring pesticide residues in fruits and vegetables on UAE markets. Central Laboratories. Ministry of Environment and Water. Al Ain, United Arab Emirates.

[6]. Nagendra. 2002 . Economic consequences of pesticide use in cabbage production in Belgaum district of Karnataka. M. Sc Thesis. University of Agricultural Sciences, Dharwad, India.

[7]. Patil, D. A and Katti, R. J. 2012. Modern agriculture, pesticides and human health : a case of agricultural labourers in western Maharashtra. Journal of Rural Development. 31 (3): 305-318.

[8]. pattern of cypermethrin in tomato. J. Bangladesh Chem. Soc.

[9]. Pinyupa, P., Kanchalee, J and Sakchai, W. 2009. "Pesticide use patterns among small-scale farmers: a case study from phitsanulok, Thailand". Southeast Asian Journal of Tropical Medicine and Public Health. 40: 401-410.

[10]. Ramakrishnan, N., Sridharan, S and Chandrasekaran, S. 2015. Insecticide usage patterns on curry leaf. International Journal of Vegetable Science. 21 (4): 318-322.

[11]. Raghu, B., Shashi Vemuri and Sreenivasa Rao, C. 2015. Studies on pesticide usage pattern and farmers knowledge on pesticide usage and technologies in open field and poly house conditions. International Journal of Nutrition and Food Sciences. 2 (7): 188

[12]. Tara, J.S. and S. Monika. 2010. Record of hemipteran insect pest diversity on Murraya koenigii (L.) Sprengel (curry leaf), a medicinally important plant from Jammu region of $\mathrm{J}$ and $\mathrm{K}$ state. The Bio scan 5(1):71-74. 